\title{
Comparison of the metabolic profiles of noncoagulating and coagulating bovine milk
}

\author{
H. Harzia,${ }^{\star} † \ddagger^{1}$ K. Kilk, $†$ I. Jõudu, ${ }^{\star} \ddagger$ M. Henno, ${ }^{\star}$ O. Kärt, ${ }^{\star}$ and U. Soomets† \\ *Institute of Veterinary Medicine and Animal Sciences, Estonian University of Life Sciences, Kreutzwaldi 46, Tartu 51006, Estonia \\ †Department of Biochemistry, Medical Faculty, University of Tartu, the Centre of Excellence for Translational Medicine, Ravila 19, \\ 50411 Tartu, Estonia \\ ¥Bio-Competence Centre of Healthy Dairy Products, Kreutzwaldi 1, 51014 Tartu, Estonia
}

\begin{abstract}
We hypothesize that, through milk composition and different milk metabolites, it is possible to characterize the technological properties (e.g., coagulation) of milk. In this research, liquid chromatography mass spectrometry was used to obtain profiles of low molecular weight organic compounds in 143 milk samples. The metabolic profiles of milk from cows were correlated with their coagulation properties. Using multivariate data analysis methods, we demonstrated that the metabolic profiles of the milk were correlated with coagulation ability. Several marker ions responsible for differential coagulation were found. Although not all affected metabolites could be identified, the most significant differences were found for carnitine and oligosaccharides. Exploitation of these results may increase the use of biomarkers to assess the coagulation ability of milk. This study represents the first large-scale metabolomic profiling of noncoagulating and coagulating bovine milk samples in Estonia.
\end{abstract}

Key words: milk coagulation, milk metabolite, tandem mass spectroscopy

\section{INTRODUCTION}

About $40 \%$ of the milk produced in Europe is used to make cheese (Rohner-Thielen, 2008), and most of the cheeses are produced by enzymatic coagulation. Good coagulation properties allow good conversion of milk solids to cheese and profits to the dairy companies. Therefore, the coagulation ability of milk influences cheese yield and quality and thus is very important.

Poor coagulation ability of milk is a problem in Italy (Malossini et al., 1996; Cassandro et al., 2008) and Finland, where about $8.6 \%$ of Finnish Ayrshire cows produce noncoagulating milk at least once during a lactation (Tyrisevä et al., 2004). A previous study (Kübarsepp et al., 2005b) in Estonia showed that about

Received April 20, 2011.

Accepted October 18, 2011.

${ }^{1}$ Corresponding author: hedi.harzia@emu.ee
8 to $9 \%$ of milk samples did not coagulate, and 17 to $20 \%$ of milk coagulated poorly with rennet.

Factors affecting milk coagulation ability have been widely studied. Milk coagulation properties are heritable; up to $40 \%$ of the variation is caused by genes (Ikonen et al., 2004; Vallas et al., 2010). The genomewide scan by Tyrisevä et al. (2008) located the genomic regions associated with the noncoagulation of milk, and 2 potential candidate genes were found (on chromosome 2, BMS1126 and on chromosome 18, BMS1355). Other factors influencing milk coagulation ability include stage of lactation, breed, nutrition, milk pH, SCC, milk composition, and milk protein genotypes (Hooydonk et al., 1986; Ostersen et al., 1997; Tyrisevä et al., 2003; Guinee et al., 2001; Auldist et al., 2002; Ikonen et al., 2004; Wedholm et al., 2006; De Marchi et al., 2007; Jõudu, 2008).

Neither genetics nor the factors described above clearly explain the noncoagulation of milk. It is possible that metabolic methods could be used to identify the most suitable milk for cheese making, based on a small number of easily detectable biomarkers. Metabolomics is the identification of the small molecule metabolites found in an organism. In clinical diagnostics and toxicology, blood or urine is most often used to assess body condition. Milk samples are easier to gather than blood samples, and in precision farming, all analyses regarding animal health could be made at milking. By analyzing milk composition, technological properties, and different milk metabolites, it is possible to evaluate numerous animal health and welfare indicators, as well as the nutritional status of animals. To date, good indicators exist for the early diagnosis of ketosis, but no such reliable, noninvasive methods have been devised for other nutrition-related metabolic diseases (Ingvartsen, 2006).

The aim of this study was to develop a method that would pinpoint the specific metabolic markers describing coagulation ability and provide us with further understanding about the mechanisms involving milk coagulation at the molecular level. If the detected metabolic markers are alterable by nutrition or selec- 
tion, this would provide an economic advantage to the dairy industry. This study was a part of a wider study describing bovine milk in Estonia.

\section{MATERIALS AND METHODS}

\section{Data Collection and Analysis}

Milk samples $(\mathrm{n}=143)$ from healthy cows of 2 different breeds, Estonian Holstein $(\mathrm{n}=121)$ and Estonian Red $(\mathrm{n}=22)$, were collected during the period from September 2008 to May 2010 by using in-line milk meters within the framework of regular animal recording from 39 different farms around Estonia. Milk samples were stabilized with bronopol (Broad Spectrum Microtabs, D\&F Control Systems Inc., Norwood, MA). Concentrations of milk fat, protein, SCC, and urea were measured from each milk sample at the Milk Analysis Laboratory of the Estonian Animal Recording Centre (Tartu), using an automated infrared milk analyzer (System 4000, Foss Electric, Hillerød, Denmark). Information on the birth and calving dates of the cows were obtained from the Estonian Animal Recording Centre. Milk pH was measured using a pH meter (MP 220, Mettler Toledo $\mathrm{GmbH}$, Greifensee, Switzerland) before analyzing coagulation ability at $20^{\circ} \mathrm{C}$ in the Laboratory of Milk Quality at Estonian University of Life Sciences (Tartu).

\section{Coagulation Analysis}

For all 143 milk samples, the rennet coagulation properties were determined by using an Optigraph (Alliance Instruments, Frepillon, France) as described by Kübarsepp et al. (2005a) at the Laboratory of Milk Quality at Estonian University of Life Sciences. Two milk coagulation parameters were measured: milk coagulation time (the time taken in minutes to start forming curd from rennet addition) and curd firmness $\left(\mathbf{E}_{30}, \mathrm{~mm}\right.$, curd firmness after $30 \mathrm{~min}$ of enzyme addition). Milk that did not form a curd was classified as noncoagulating $\left(\mathrm{n}=27, \mathrm{E}_{30}=0 \mathrm{~mm}\right)$ and that with particularly good coagulation ability $\left(\mathrm{n}=27, \mathrm{E}_{30} \geq 40 \mathrm{~mm}\right)$ was classified as well coagulating. The remaining 89 intermediate samples were classified as poor or good, based on their coagulation ability. The Optigraph recorded some curd firmness $\left(\mathrm{E}_{30}>0.89 \mathrm{~mm}\right)$ in milk with poor coagulation properties, but following further observation, complete coagulation did not occur. Milk with good coagulation ability did form a firm curd $\left(20<\mathrm{E}_{30}<40 \mathrm{~mm}\right)$, but such samples were not identified as well-coagulating because the $\mathrm{E}_{30}$ value did not reach $40 \mathrm{~mm}$.

\section{Sample Preparation}

The milk samples were stored at $-20^{\circ} \mathrm{C}$ until analyzed for metabolites. Frozen samples were thawed in a water bath at temperature $40^{\circ} \mathrm{C}$, and a 5 -mL aliquot of milk was centrifuged (Refrigerated Centrifuge 2-16K, SigmaAldrich, St. Louis, MO) at $3,000 \times g$ for $10 \mathrm{~min}$ at $4^{\circ} \mathrm{C}$ to remove fat. A 3-mL sample of skim milk was mixed with $3 \mathrm{~mL}$ of $3 \%$ TCA solution (ACS reagent, $\geq 99.5 \%$ purity, Sigma-Aldrich) and centrifuged at 17,000 $\times g$ for $15 \mathrm{~min}$ at $4^{\circ} \mathrm{C}$. The supernatant was mixed with an equal volume of acetonitrile (LC-MS Chromasolv, $\geq 99.9 \%$ purity, Sigma-Aldrich) and centrifuged (Hettich Zentrifugen Universal 32R, GMI Inc., Ramsey, NJ) at $14,000 \times g$ for $15 \mathrm{~min}$ at $4^{\circ} \mathrm{C}$. The supernatant was collected and injected into the mass spectrometer for further analyses.

\section{Mass Spectrometry}

Mass spectrometry analyses were carried out on the triple quadrupole linear ion trap hybrid liquid chromatography-tandem mass spectrometer (LC-MS/MS; 3200 Q TRAP; AB Sciex Instruments, Foster City, $\mathrm{CA}$ ). The sample was injected into the MS using the SIL-20A autosampler (Shimadzu, Kyoto, Japan). The mobile phase ( $80 \%$ acetonitrile in water) was delivered by LC-20AD pumps (Shimadzu). Positive ions formed in the source were scanned in enhanced mode within the $m / z$ mass range 50 to 1,500 . The scan rate was $1,000 \mathrm{amu} / \mathrm{s}$. Curtain and nebulizer gas had settings of 10 and 20, respectively. Ionization was performed at room temperature. The ion spray voltage was set at 4,500 V. The entrance and declustering potential and the collision energy were set at $10 \mathrm{~V}$. The system was controlled by the Analyst 1.4.2 software (Applied Biosystems Inc., Foster City, CA).

For preliminary compound identification, $\mathrm{C}_{18}$ (Luna $3-\mu \mathrm{m}$ C18 100A, $100 \times 2.00 \mathrm{~mm}$, Phenomenex, Torrance, CA) and hydrophilic interaction liquid chromatography (HILIC, Luna 5- $\mu$ m HILIC 200A, $150 \times 3.00$ $\mathrm{mm}$, Phenomenex) columns were used. The gradient for retention time studies was as follows: 5 min isocratic at $95 \%$ acetonitrile in water, gradient decline to $5 \%$ acetonitrile in water within $40 \mathrm{~min}, 10 \mathrm{~min}$ at $5 \%$ acetonitrile in water.

\section{Statistical Analysis}

To reduce the effects of error, MS spectral data were pre-processed by binning data to atomic mass unit resolution. Statistical analyses of the data were made using in-house R 2.8.1/BioConductor algorithms ( $R$ Development Core Team, 2008). Statistical significance between $\mathrm{m} / z$ intensities in the spectra of noncoagulating and well-coagulating milk was determined by Student $t$-tests, and correlations were found using Pearson correlation analyses. Results were assessed with princi- 
pal component analysis (PCA) and a heat-map that displayed the distribution of signal intensities relative to the mean at respective $m / z$ values. The $m / z$ values were ranked based on calculated statistical differences, and only significant values are presented.

\section{RESULTS AND DISCUSSION}

\section{Characteristics of Analyzed Milk Samples}

Parallel to the MS-based metabolic profiling study, all milk samples were analyzed for the major milk compounds. Mean values of DIM, SCS [SCS $=\ln (\mathrm{SCC})]$, fat, urea, and protein concentrations, $\mathrm{pH}$, and coagulation parameters for all 4 groups of sampled milk are shown in Table 1.

Characteristics for the well-coagulating and noncoagulating groups were compared. Significant differences were found for $\mathrm{pH}\left(P=9.54 \times 10^{-23}\right)$, SCS $(P=1.60$ $\left.\times 10^{-5}\right)$, fat $\left(P=8.18 \times 10^{-5}\right)$, urea $\left(P=1.69 \times 10^{-7}\right)$, and protein $\left(P=1.99 \times 10^{-5}\right)$ contents (Table 1$)$.

According to previous studies (Tyrisevä et al., 2003; Ikonen et al., 2004; Jõudu, 2008) milk coagulation should be optimal at the beginning of lactation, worst during mid-lactation, and improving during late lactation. All of the well-coagulating milk samples were from different stages of lactation; DIM varied from 34 to 320. Noncoagulating milk samples were collected from d 93 to d 338 of lactation and thus did not represent only mid-lactation, as anticipated.

Besides stage of lactation, milk coagulation ability differs at different $\mathrm{pH}$ values and SCC levels. In this study, noncoagulating milk had a higher $\mathrm{pH}(\mathrm{pH}=$ 6.85 to 7.11 ) than well-coagulating milk $(\mathrm{pH}=6.54$ to 6.75). This was observed previously (Okigbo et al., 1985; Ikonen et al., 2004). Changes in milk pH can be due to the onset of udder inflammation or stage of lactation (Harmon, 1994; McCarthy and Singh, 2009).
All 143 analyzed milk samples were collected from different farms with different feeding practices from cows with no identified diseases during regular animal recording. Therefore, it was not possible to identify the cause of the elevated levels of $\mathrm{pH}$ in noncoagulating milk samples in this study.

Somatic cell count can be used as an indicator of udder health, which may affect coagulation ability (Okigbo et al., 1985; O'Brien et al., 2001). In turn, SCC in milk can be affected by stage of lactation, stress, age of the cow, and milking frequency (Kelly, 2003). An elevated level of SCC can occur in both well-coagulating and poorly coagulating milks (Jõudu, 2008), as was the case in our study. To eliminate a possible effect of SCC, a separate database comprising milk samples with an SCC $<5.0 \times 10^{5}$ cells $/ \mathrm{mL}$ was prepared that comprised 93 samples, including 8 noncoagulating and 8 wellcoagulating samples. The SCC in our 2 new groups (noncoagulating and well-coagulating with low SCC) were still significantly different $(P=0.003)$, as was $\mathrm{pH}\left(P=1.41 \times 10^{-7}\right)$, fat $(P=0.013)$, and protein $(P$ $=0.0001)$ content. All 8 of the well-coagulating milk samples were from cows in late lactation (238 to 320 DIM), and the same was observed for the noncoagulating milk samples (215 to 284 DIM).

\section{Global Metabolite Profiles}

The main hypothesis of this study was that MS analysis of low molecular weight milk compounds could pinpoint metabolites that are correlated with coagulation ability. The validity of this hypothesis, and subsequent identification of the key metabolites, would lead to a better understanding of the mechanisms behind unsatisfactory coagulation. As a first step, MS analyses were performed with no targeting of a specific group of metabolites within the mass range $\mathrm{m} / \mathrm{z} 50$ to 1,500 (nontargeted analysis). Illustrative

Table 1. Mean values (SD in parentheses) of DIM, SCS, fat, urea, and protein concentration, $\mathrm{pH}$, and $\mathrm{E}_{30}$ for all 143 milk samples

\begin{tabular}{|c|c|c|c|c|}
\hline \multirow[b]{2}{*}{ Trait $^{1}$} & \multirow[b]{2}{*}{$\begin{array}{l}\text { Noncoagulating } \\
\quad(\mathrm{n}=27)\end{array}$} & \multicolumn{2}{|c|}{ Intermediate } & \multirow[b]{2}{*}{$\begin{array}{l}\text { Well-coagulating } \\
\quad(\mathrm{n}=27)\end{array}$} \\
\hline & & $\begin{array}{c}\text { Poor } \\
(\mathrm{n}=77)\end{array}$ & $\begin{array}{c}\text { Good } \\
(\mathrm{n}=12)\end{array}$ & \\
\hline DIM & $244^{\mathrm{a}}(55)$ & $182^{\mathrm{b}}(69)$ & $241^{\mathrm{a}}(78)$ & $251^{\mathrm{ab}}(68)$ \\
\hline Fat, $\%$ & $3.82^{\mathrm{a}}(1.19)$ & $3.86^{\mathrm{a}}(1.03)$ & $4.24^{\mathrm{a}}(0.76)$ & $5.05^{\mathrm{b}}(0.82)$ \\
\hline Protein, \% & $3.71^{\mathrm{a}}(0.43)$ & $3.58^{\mathrm{a}}(0.37)$ & $3.76^{\mathrm{a}}(0.32)$ & $4.19^{\mathrm{b}}(0.32)$ \\
\hline Urea, mg/dL & $12.45^{\mathrm{a}}(6.48)$ & $23.00^{\mathrm{b}}(9.12)$ & $22.86^{\mathrm{b}}(6.84)$ & $25.33^{\mathrm{b}}(7.92)$ \\
\hline $\mathrm{pH}$ & $7.00^{\mathrm{a}}(0.11)$ & $6.72^{\mathrm{b}}(0.11)$ & $6.65^{\mathrm{c}}(0.06)$ & $6.62^{\mathrm{c}}(0.05)^{\prime}$ \\
\hline SCS & $6.97^{\mathrm{a}}(1.22)$ & $5.21^{\mathrm{b}}(1.92)$ & $5.49^{\mathrm{b}}(1.23)$ & $5.34^{\mathrm{b}}(1.29)$ \\
\hline $\mathrm{E}_{30}, \mathrm{~mm}$ & $0.00^{\mathrm{a}}(0.00)$ & $20.52^{\mathrm{b}}(10.56)$ & $28.78^{\mathrm{c}}(6.61)$ & $47.22^{\mathrm{d}}(3.65)$ \\
\hline $\mathrm{RCT}, \min$ & $21.68^{\mathrm{a}}(14.05)$ & $16.06^{\mathrm{b}}(4.46)$ & $9.98^{\mathrm{c}}(1.46)$ & $8.92^{\mathrm{d}}(1.10)$ \\
\hline
\end{tabular}

${ }^{\mathrm{a}-\mathrm{d}}$ Means within a row with different superscripts differ $(P<0.05)$.

${ }^{1} \mathrm{SCS}=\ln (\mathrm{SCC}) ; \mathrm{E}_{30}=$ curd firmness after $30 \mathrm{~min} ; \mathrm{RCT}=$ milk coagulation time. 
A

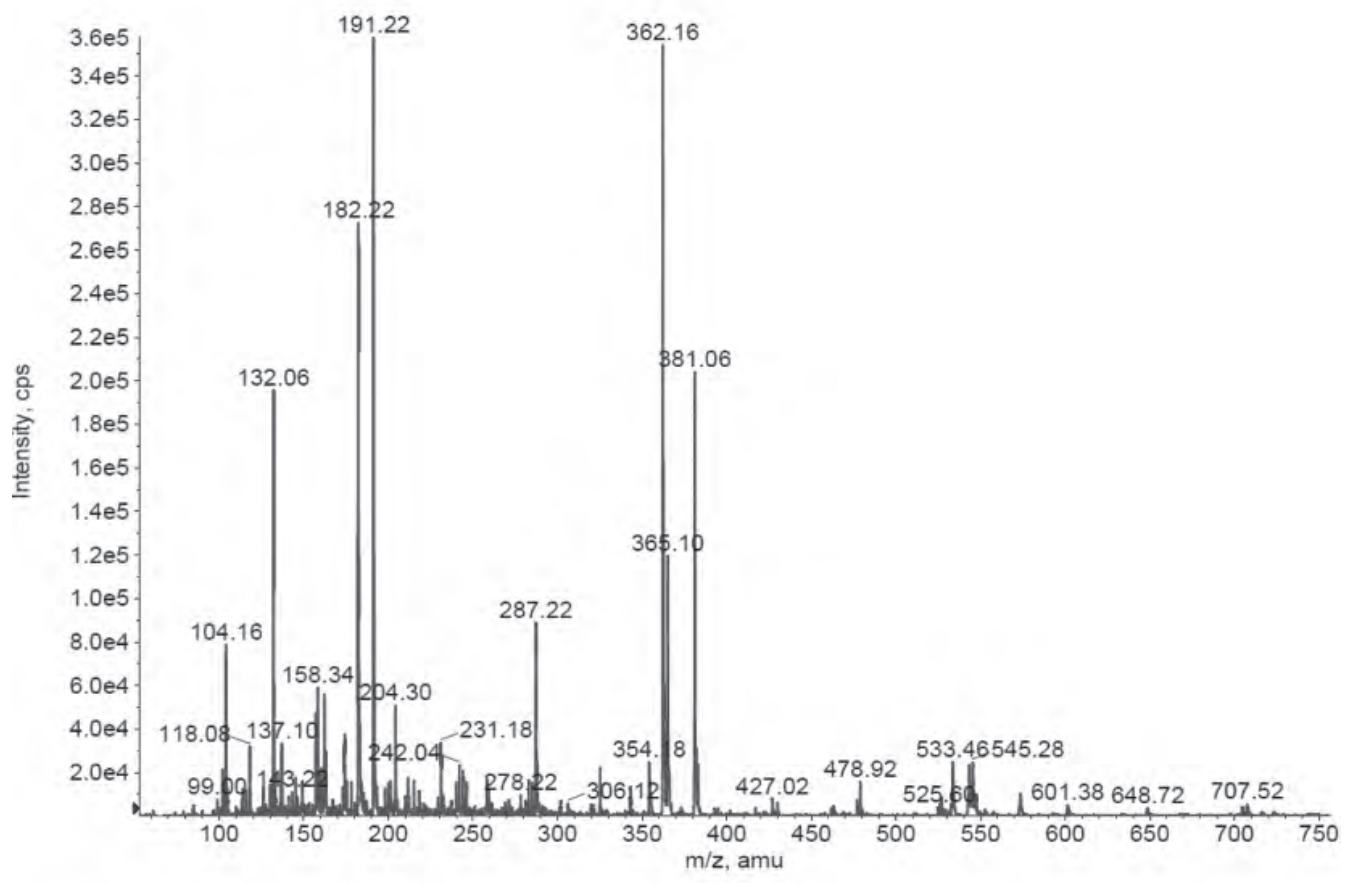

B

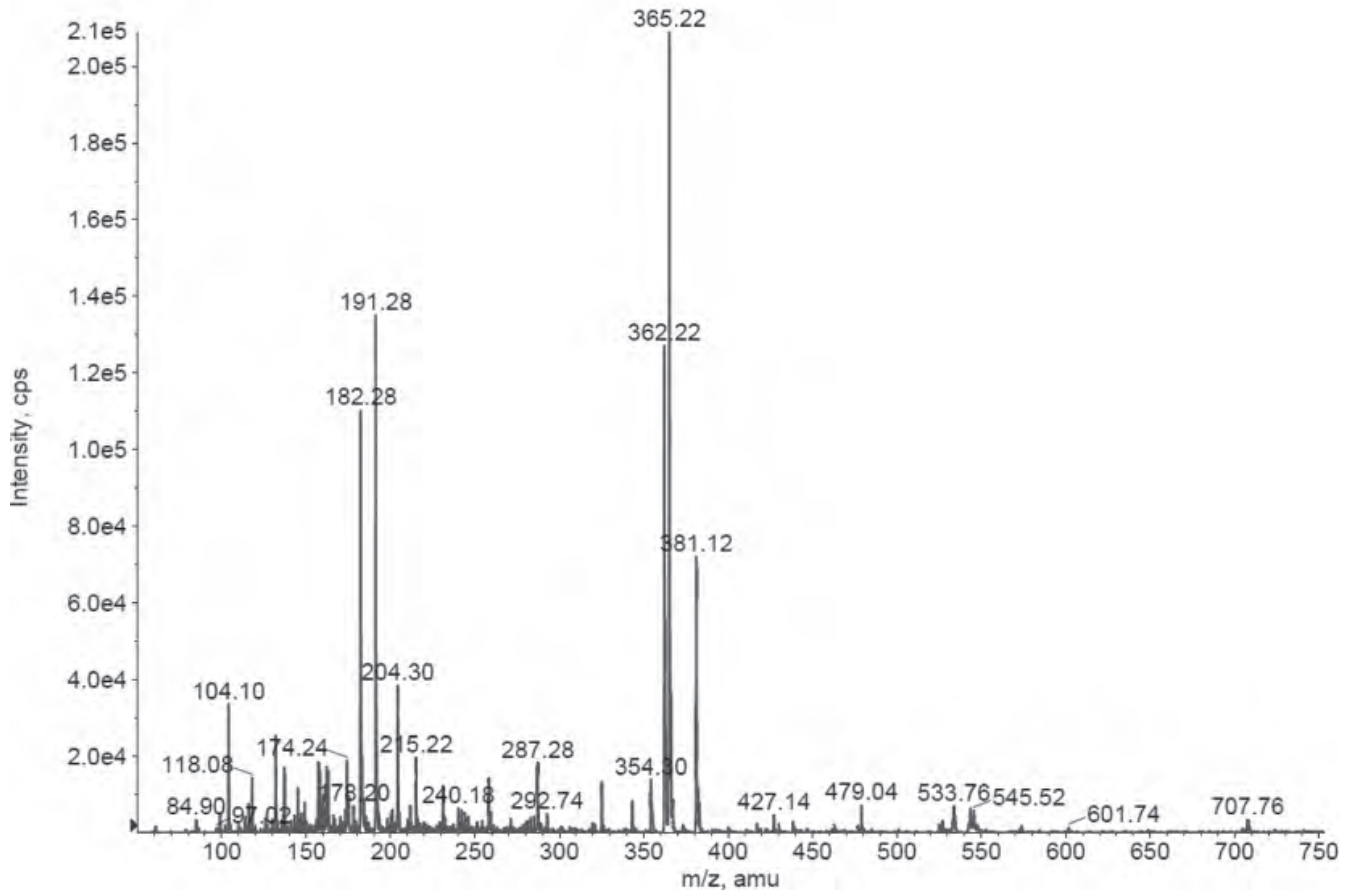

Figure 1. Spectra of (A) noncoagulating milk and (B) well-coagulating milk $(\mathrm{m} / z$ 50-750).

spectra of typical examples of noncoagulating and well- Although differences between the well-coagulating coagulating milks are presented in Figures 1A and 1B, and noncoagulating milk samples were apparent from respectively. individual spectra, PCA and calculations for statisti- 
cally significant differences were performed to better identify these differences.

$\boldsymbol{P C A}$. First, the metabolic spectra of all $143 \mathrm{milk}$ samples (all 4 coagulating groups) were analyzed. The samples with intermediate coagulation ability were distributed around the same area as the well-coagulating and noncoagulating samples without forming a well-defined cluster of their own (Figure 2A). We observed that, among the intermediate group, the better coagulating samples were located closer to the well-coagulating samples. Figure $2 \mathrm{~A}$ shows a plot of the most important components reflecting $91.2 \%$ of the total variation [principal component (PC)1: $86 \%$ and PC2: 5.2\%].

Subsequently, only the well-coagulating and noncoagulating milk samples were analyzed by PCA. The results (Figure 2B) showed 2 distinct clusters. Wellcoagulating and noncoagulating milk spectra were separated by $\mathrm{PC} 2$ (y-axis), with all well-coagulating samples positioned above a threshold, and all noncoagulating samples below this threshold. Principal component 1 (x-axis) and PC3 did not differentiate between these 2 groups significantly. Thus, we concluded that, in addition to other sources of variation, a specific signature exists for well-coagulating milk compared with noncoagulating milk. The same outcome was observed for well-coagulating and noncoagulating milk samples from the SCC-corrected database (Figure 2C).

Heat-Map Analysis. To display the distribution of signal intensities relatively to the mean at respective $m / z$ values, a heat-map analysis was produced (Figure 3). A heat-map is a structured display of data where different colors represent different expression levels of the metabolites. The $m / z$ values were first ranked based on the calculated statistical differences between the signal intensities in the noncoagulating and wellcoagulating groups, and only the most significant differences are shown. Figure 3 shows that alterations in both directions were present: some compounds were more abundant in well-coagulating milk and others in noncoagulating milk. Signals with a difference of 1 or 2 amu, and with a very similar pattern among samples, are likely to be isotopes of the same substance. Even considering this, the number of markers found was not limited to a small number of metabolites, indicating that more than a single compound is involved in the reduced coagulation capacity of some milks. In the intermediate group, samples with poor coagulation ability were more similar to noncoagulating milk, whereas most of the others were more similar to the well-coagulating milk samples. To further illustrate this, the heat-map analyses were carried out separately on the intermediate group (Figure 3B). A difference was observed even among the samples with poor and good coagulation abilities. Heat-map analysis was also carried out on the SCC-corrected database, comparing noncoagulating and well-coagulating milk samples. Figure $3 \mathrm{C}$ shows the $25 \mathrm{~m} / z$ values most significantly different within this data set. Although the noncoagulating and well-coagulating milks were significantly different $(P \leq 0.05)$, the intermediate group milks were not significant. Compounds with $m / z 534,601$, and 162 were represented on all heat-maps; signals were more intense in samples with better coagulation ability.

\section{Correlation Analyses}

Coagulation analyses were carried out on all 143 milk samples, and coagulation time was found to be positively correlated with milk $\mathrm{pH}(\mathrm{R}=0.48)$. Curd firmness had a highly negative correlation with $\mathrm{pH}(\mathrm{R}=-0.80)$ and coagulation time and curd firmness were negatively correlated $(\mathrm{R}=-0.58)$. Okigbo et al. (1985) also noted that coagulation time was positively correlated with milk $\mathrm{pH}(\mathrm{R}=0.58)$; curd firmness had a negative correlation $(\mathrm{R}=-0.53)$ with $\mathrm{pH}$; and coagulation time and curd firmness were highly negatively correlated $(\mathrm{R}=-0.86)$. Ikonen et al. (2004) and Kübarsepp et
A

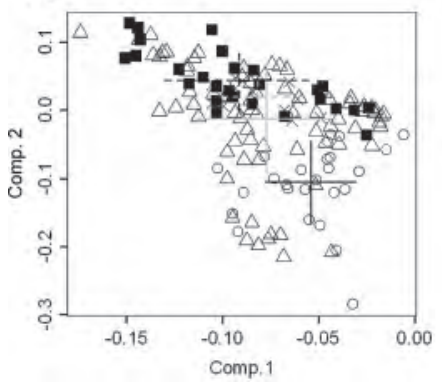

B

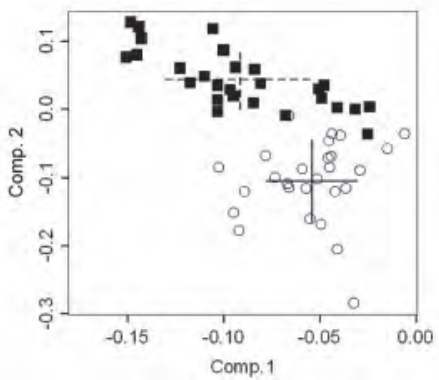

C

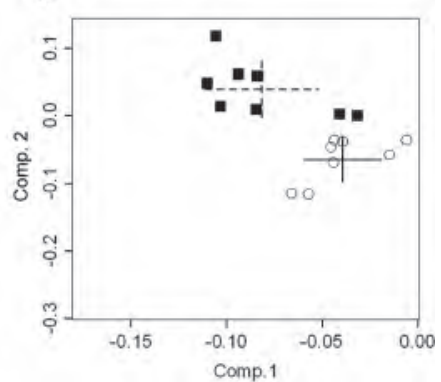

Figure 2. Principal component (comp.) analyses (PCA) of all 143 milk samples: $($ A) well- $(\mathbf{\square})$, poor $(\Delta)$, good $(\times)$, and noncoagulating $(\bigcirc)$

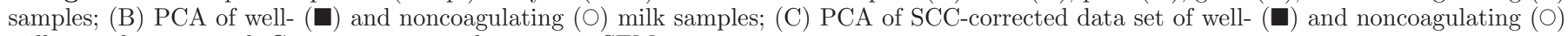
milk samples was used. Crosses represent the mean \pm SEM. 

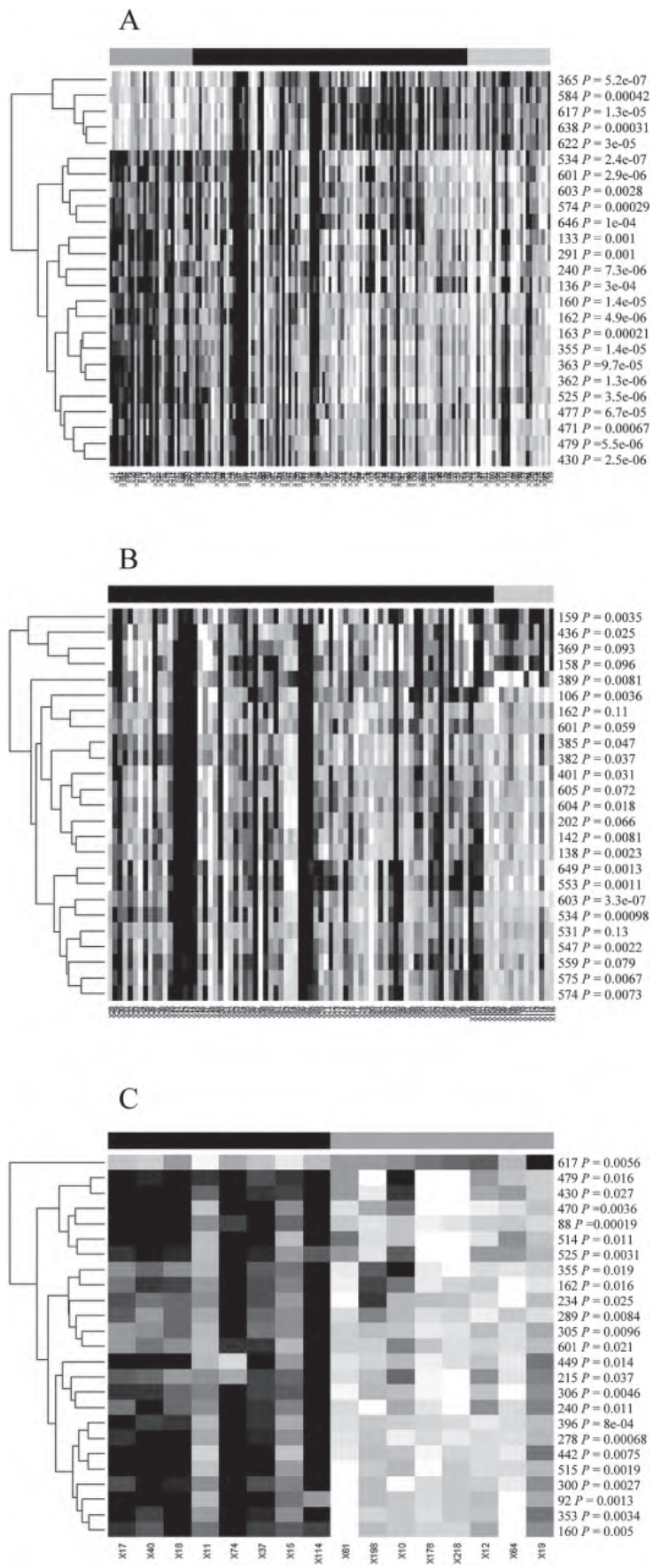

Figure 3. (A) Heat map of noncoagulating (dark gray bar on top left), intermediate (black bar on top center), and well-coagulating (light gray bar on top right) milk samples. Statistical comparison with Student $t$-test was calculated between well-coagulating and noncoagulating groups. The 25 most significantly different $m / z$ values with respective $P$-values can be seen in the right-hand side. Rows are arranged into clusters (dendrogram on left-hand side) based on pattern similarities. The lighter the shading of a data point, the more intense the signal is compared with the mean value for the respective $\mathrm{m} / \mathrm{z}$ among all analyses. Gray points are close to the mean and dark tones indicate signal intensities below the mean; (B) heat map of milks with poor (black bar) and good (gray bar) coagulation ability; (C) heat map of noncoagulating (black bar) and well-coagulating (gray bar) milks. al. (2005b) found identical (in the same direction) but weaker phenotypic correlations in their large-scale studies covering a few thousand samples than were found in the current study. The correlation between coagulation time and milk $\mathrm{pH}$ was moderate $(\mathrm{R}=0.29$ and $\mathrm{R}=$ 0.39 , respectively), as was the correlation between SCS and milk $\mathrm{pH}(\mathrm{R}=0.26$ and $\mathrm{R}=0.19$, respectively). Milk $\mathrm{pH}$ had weak negative correlation with curd firmness $(\mathrm{R}=-0.18$ and $\mathrm{R}=-0.15$, respectively).

No significant correlations were found between curd firmness, MS signals, and herd or breed data, perhaps because of the relatively large number of herds compared with the total number of samples. With simultaneous comparison of 39 herds, the putative herdspecific markers might cancel each other out as noise in biological variance. The accompanied increase in noise may also make breed-specific markers harder to detect.

It has been suggested that the poor coagulation ability of milk can be predicted based on SCC and milk pH (Grandison and Ford, 1986; Ikonen et al., 2004); no known factors independently cause the noncoagulation of milk. In addition to correlating classical milk characteristics with each other and with coagulation ability, we wanted to know whether SCS, pH, coagulation ability, or $\mathrm{E}_{30}$ were correlated with LC-MS/MS signals. The strongest negative correlation $(\mathrm{R}=-0.30)$ was found between SCS and $m / z=535$ (Table 2), and the highest positive correlation $(\mathrm{R}=0.61)$ between SCS and $m / z=1,110$. From the lower mass range under $m / z 499$, no significant correlation with SCS was found. In general, SCS was weakly correlated $(\mathrm{R}=0.28)$ with the discovered markers. The most positive correlation with SCS was to signals with an $m / z$ of over 1,000 . The mass range, and fact that many signals showed similar correlations, suggests that a high SCC causes higher

Table 2. Correlation coefficients of SCS, pH, and curd firmness $\left(\mathrm{E}_{30}\right)$ with markers identified by $m / z$

\begin{tabular}{lrrr}
\hline$m / z$ & SCS & $\mathrm{pH}$ & \multicolumn{1}{c}{$\mathrm{E}_{30}$} \\
\hline 160 & -0.01 & -0.15 & 0.20 \\
162 & -0.05 & -0.29 & 0.34 \\
240 & 0.09 & -0.05 & 0.18 \\
362 & -0.09 & -0.04 & 0.12 \\
365 & 0.17 & 0.34 & -0.18 \\
430 & -0.00 & -0.17 & 0.25 \\
479 & -0.06 & -0.23 & 0.31 \\
525 & -0.02 & -0.02 & 0.06 \\
534 & -0.29 & -0.44 & 0.44 \\
535 & -0.30 & -0.47 & 0.48 \\
584 & 0.50 & 0.41 & -0.36 \\
601 & 0.16 & -0.08 & 0.17 \\
617 & 0.48 & 0.44 & -0.39 \\
622 & 0.53 & 0.31 & -0.28 \\
638 & 0.47 & 0.36 & -0.27 \\
851 & 0.54 & 0.64 & -0.52 \\
1,046 & 0.49 & 0.63 & -0.53 \\
1,110 & 0.61 & 0.45 & -0.40 \\
\hline
\end{tabular}


background noise from peptides and oligosaccharides. The strongest negative correlation $(\mathrm{R}=-0.47)$ was between $\mathrm{pH}$ and $m / z=535$, and the most positive correlation between $\mathrm{pH}$ and $m / z=851(\mathrm{R}=0.64)$. No significant correlations $(\mathrm{R}=-0.08)$ were found between milk $\mathrm{pH}$ and the identified markers in the mass range under $m / z$ 499. A moderate positive correlation $(\mathrm{R}=$ $0.29)$ was noted in the mass range of $m / z 500$ to 999 , and a stronger positive correlation $(\mathrm{R}=0.40)$ in the mass range of $m / z 1,000$ to 1,500 .

\section{Analysis of Markers}

Signals with significant differences between wellcoagulating and noncoagulating milks were selected for further analysis (Figure 3A, B, and C). First, to specify the molecular weights, ion charge $(z)$ values were determined (Table 3). Surprisingly, a tendency was observed for the signals that were stronger in well-coagulating milks to be doubly charged. Signals from the noncoagulating milks had a value of $z=1$. With the values of charges known, molecular weights were calculated and most were observed to be above $500 \mathrm{amu}$. Nonpolymeric compounds rarely exceed a molecular weight of 600 amu (Kind and Fiehn, 2007). Masses around $m / z$ 1,000 could indicate lipids, peptides, or oligosaccharides. The hydrophobicity of the selected markers was assessed by $\mathrm{C}_{18}$ and HILIC columns. None of the markers had significant interactions with the $\mathrm{C}_{18}$ analytical column, implying a lack of hydrophobicity. From the HILIC column, the compounds eluted after 27 min (Table 3).

Fragmentation analysis was carried out and results were compared with the spectra in the human metabolome database (htttp://www.hmdb.ca). A signal of $m / z$ $=162$ was found to match carnitine, but no defined match was found for the others. Yet it was noted that the spectra shared similarities. The first common characteristic was a repetitive loss of $18 \mathrm{amu}$; second, fragments with $m / z$ values of 99,180 , and 261 were shared by many compounds; and third, compounds with higher mass yielded fragments matching molecular weights of smaller compounds. Taken together, the fragmentation spectra imply the presence of oligosaccharides. This was further tested by determining fragmentation and HILIC retention times of glucose, sucrose, lactose, and $\mathrm{N}$-acetyllactosamine (Table 3 ). Beside protonated molecular ions, sodium and potassium adducts and [M$\left.\mathrm{H}_{2} \mathrm{O}\right]^{+}$ions were observed. Signal $m / z=365$, found in commercial $\mathrm{N}$-acetyllactosamine (Sigma-Aldrich) and believed to represent $\left[\mathrm{M}-\mathrm{H}_{2} \mathrm{O}\right]^{+}$ion, yielded fragments

Table 3. Characteristics of mass spectrometry signals that have most significant differences between well-coagulating and noncoagulating milks

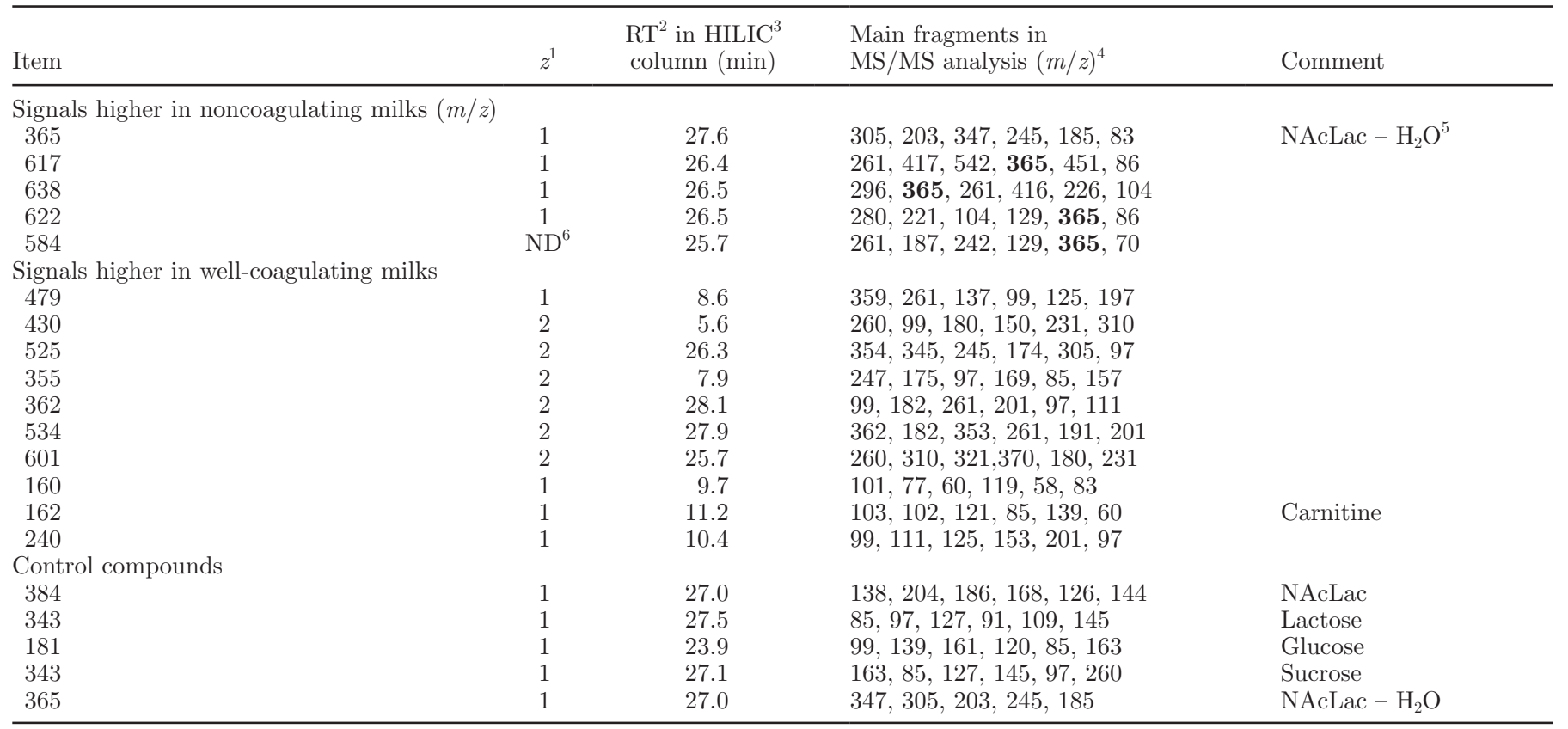

${ }^{1}$ Ion charge.

${ }^{2}$ Retention time (min).

${ }^{3}$ Hydrophilic interaction liquid chromatography.

${ }^{4}$ The repeating fragment of $m / z=365$ is in bold.

${ }^{5} \mathrm{~N}$-acetyllactosamine as the $\left[\mathrm{M}-\mathrm{H}_{2} \mathrm{O}\right]^{+}$ion.

${ }^{6}$ For one compound, no clear isotopic distribution could be obtained and determination of $z$ was therefore not possible (ND). 
that matched well with an unknown signal $(\mathrm{m} / z=$ 365 ). Because of the structural similarities of various saccharides, this identification should be regarded with caution. Interestingly, in all of the 4 signals that were elevated in noncoagulating milks, a fragment with $\mathrm{m} / \mathrm{z}$ $=365$ was observed. No marker from the well-coagulating milk yielded such a fragment. Further analysis to determine the exact oligosaccharides affecting coagulation ability are necessary.

\section{CONCLUSIONS}

This study found correlations between milk technological properties (in this case, coagulation) and its metabolome. This study confirmed that such correlations exist and could open the way to improve these technological properties through animal nutrition or selection, which could influence the level of the identified metabolites. Our results show that it is possible, using MS analyses, to detect signals that correlate with either the coagulation capacity or other parameters (e.g., pH and SCC) believed to influence the coagulation process. It is not yet possible to describe in detail the mechanism whereby low molecular weight compounds enhance or inhibit coagulation, but the results presented represent a first step in this direction.

\section{ACKNOWLEDGMENTS}

This research was carried out by the Bio-Competence Centre of Healthy Dairy Products and was co-financed by the European Community's Regional Development Fund within the framework of the Competence Centre Program of the Enterprise Estonia, project no. EU30002, targeted finance project SF0170165s08, and Estonian Science Foundation grants 7494 and 7856.

\section{REFERENCES}

Auldist, M., C. Mullins, B. O'Brien, B. T. O'Kennedy, and T. Guinee. 2002. Effect of cow breed on milk coagulation properties. Milchwissenschaft 57:140-143.

Cassandro, M., A. Comin, M. Ojala, R. Dal Zotto, M. De Marchi, L. Gallo, P. Carnier, and G. Bittante. 2008. Genetic parameters of milk coagulation properties and their relationships with milk yield and quality traits in Italian Holstein cows. J. Dairy Sci. 91:371-376.

De Marchi, M., R. Dal Zotto, M. Cassandro, and G. Bittante. 2007. Milk coagulation ability of five dairy cattle breeds. J. Dairy Sci. 90:3986-3992.

Grandison, A. S., and G. D. Ford. 1986. Effects of variations in somatic-cell count on the rennet coagulation properties of milk and on the yield, composition and quality of cheddar cheese. J. Dairy Res. 534:645-655.

Guinee, T. P., E. O. Mulholland, B. O'Brien, and J. J. Murphy. 2001. Effect of diet quality on the suitability of mid-lactation bovine milk for cheddar cheese manufacture. Aust. J. Dairy Technol. $56: 3-8$.

Harmon, R. J. 1994. Physiology of mastitis and factors affecting somatic cell counts. J. Dairy Sci. 77:2103-2112.
Hooydonk, A. C. M., I. J. Boerrigter, and H. G. Hagedoorn. 1986. pH-induced physico-chemical changes of casein micelles in milk and their effect on renneting. 2. Effect of $\mathrm{pH}$ on renneting of milk. Neth. Milk Dairy J. 40:297-313.

Ikonen, T., S. Morri, A. M. Tyrisevä, O. Ruottinen, and M. Ojala. 2004. Genetic and phenotypic correlations between milk coagulation properties, milk production traits, somatic cell count, casein content, and pH of milk. J. Dairy Sci. 87:458-467.

Ingvartsen, K. L. 2006. Feeding- and management-related diseases in the transition cow-Physiological adaptations around calving and strategies to reduce feeding-related diseases. Anim. Feed Sci. Technol. 126:175-213.

Jõudu, I. 2008. Effect of milk protein composition and genetic polymorphism on milk rennet coagulation properties. PhD Thesis. Estonian University of Life Sciences, Tartu. http://dspace.emu.ee/ jspui/bitstream/10492/113/1/Thesis_Joudu_2008.pdf.

Kelly, A. L. 2003. Milk Quality and Udder Health. Test Methods and Standards. Pages 1995-2002 in Encyclopedia of Dairy Sciences. Vol. 3. H. Roginski, J. W. Fuquay, and P. F. Fox, ed. Academic Press, London, UK.

Kind, T., and O. Fiehn. 2007. Seven Golden Rules for heuristic filtering of molecular formulas obtained by accurate mass spectrometry. BMC Bioinformatics 8:105-125.

Kübarsepp, I., M. Henno, O. Kärt, and T. Tupasela. 2005a. A comparison of the methods for determination of the rennet coagulation properties of milk. Acta Agric. Scand. Anim. Sci. 55:145-148.

Kübarsepp, I., M. Henno, H. Viinalass, and D. Sabre. 2005b. Effect of $\kappa$-casein and $\beta$-lactoglobulin genotypes on the milk rennet coagulation properties. Agron. Res. 3:55-64.

Malossini, F., S. Bovolenta, C. Piras, M. DallaRosa, and W. Ventura. 1996. Effect of diet and breed on milk composition and rennet coagulation properties. Ann. Zootech. 45:29-40.

McCarthy, O. J., and H. Singh. 2009. Physicochemical properties of milk. Pages 691-758 in Advanced Dairy Chemistry: Volume 3: Lactose, Water, Salts, and Minor Constituents. P. L. H. McSweeney and P. F. Fox, ed. Springer, London, UK.

O'Brien, B., W. J. Meaney, D. McDonagh, and A. Kelly. 2001. Influence of somatic cell count and storage interval on composition and processing characteristics of milk from cows in late lactation. Aust. J. Dairy Technol. 56:213-218.

Okigbo, L. M., G. H. Richardson, R. J. Brown, and C. A. Ernstrom. 1985. Variation in coagulation properties of milk from individual cows. J. Dairy Sci. 68:822-828.

Ostersen, S., J. Foldager, and J. E. Hermansen. 1997. Effects of stage of lactation, milk protein genotype and body condition at calving on protein composition and renneting properties of bovine milk. J. Dairy Res. 64:207-219.

R Development Core Team. 2008. R: A language and environment for statistical computing. R Foundation for Statistical Computing, Vienna, Austria. http://www.R-project.org.

Rohner-Thielen, E. 2008. From grass to glass: A look at the dairy chain. Eurostatistics 76:1-8.

Tyrisevä, A. M., K. Elo, A. Kuusipuro, V. Vilva, I. Janonen, H. Karjalainen, T. Ikonen, and M. Ojala. 2008. Chromosomal regions underlying noncoagulation of milk in Finnish Ayrshire cows. Genetics 180:1211-1220.

Tyrisevä, A. M., T. Ikonen, and M. Ojala. 2003. Repeatability estimates for milk coagulation traits and non-coagulation of milk in Finnish Ayrshire cows. J. Dairy Res. 70:91-98.

Tyrisevä, A. M., T. Vahlsten, O. Ruottinen, and M. Ojala. 2004. Noncoagulation of milk in Finnish Ayrshire and Holstein-Friesian cows and effect of herds on milk coagulation ability. J. Dairy Sci. 87:3958-3966.

Vallas, M., H. Bovenhuis, T. Kaart, K. Parna, H. Kiiman, and E. Parna. 2010. Genetic parameters for milk coagulation properties in Estonian Holstein cows. J. Dairy Sci. 93:3789-3796.

Wedholm, A., L. B. Larsen, H. Lindmark-Mansson, A. H. Karlsson, and A. Andren. 2006. Effect of protein composition on the cheesemaking properties of milk from individual dairy cows. J. Dairy Sci. 89:3296-3305. 